\title{
FABP-2 and PPAR- $\gamma$ Haplotype as Risk Factors for Dyslipidemia in a Type 2 Diabetes Mellitus Population of Santa Rosa del Conlara, San Luis, Argentina
}

\author{
Susana Siewert, María Florencia Olmos Nicotra, Irma Ines Gonzalez, Gustavo Fernandez, \\ Marta Susana Ojeda* \\ Laboratory of Diabetes, Department of Biochemistry and Biological Sciences, School of Chemistry, \\ Biochemistry and Pharmacy, National University of San Luis, San Luis, Argentina \\ Email: "msojeda@unsl.edu.ar
}

Received 26 July 2014; revised 12 September 2014; accepted 15 October 2014

Copyright (C) 2014 by authors and OALib.

This work is licensed under the Creative Commons Attribution International License (CC BY).

http://creativecommons.org/licenses/by/4.0/

(c) (i) Open Access

\section{Abstract}

Introduction: Type 2 Diabetes Mellitus (T2DM) is a complex disorder caused by the interaction between genetic predisposition and environmental factors. Genetics plays an important role on lipid homeostasis. Many genes are involved in the lipid metabolism, such as FABP-2 and PPAR- $\gamma$. Aim: To evaluate the association between specific SNPs and haplotypes of the FABP-2 and PPAR- $\gamma$ genes with T2DM and lipid profile in an Argentinean population. Methods: The FABP-2 (rs1799883) and PPAR- $\gamma$ (rs1801282) polymorphisms were genotyped and analyzed in association with lipid profile and T2DM, separately and also combined in haplotypes. Results: The frequency of the rare Thr54 allele of the FABP-2 polymorphism in control $(0.33)$ was not different from the frequency in T2DM (0.27), whereas the frequency of the rare Ala12 allele of the PPAR- $\gamma$ polymorphism in control was different from the frequency in T2DM $(0.26$ and 0.14 , respectively; $p=0.0031)$. Frequencies of haplotypes for these two single-nucleotide polymorphisms differed significantly in control and T2DM. Haplotype association analysis showed the associations between ThrPro haplotype and TG levels $(\mathrm{OR}=2.520 ; 95 \% \mathrm{CI}=1.139-5.575 ; \mathrm{p}=0.027)$ and between ThrPro haplotype and TC and LDL-c levels when compared to AlaPro haplotype (difference $=0.175,95 \% \mathrm{CI}=0068$ $0.499, \mathrm{p}<0.0001$; difference $=0.052,95 \% \mathrm{CI}=0.017-0.158, \mathrm{p}<0.0001$, respectively). Conclusions: These results from a haplotype analysis show for the first time that genetic combinations of alleles of the FABP-2 and PPAR- $\gamma$ gene could play a role in the susceptibility to develop dyslipemia in T2DM.

\section{Keywords}

Type 2 Diabetes Mellitus, FABP-2, PPAR- $\gamma$, Polymorphism, Haplotypes, Dyslipemia

\footnotetext{
${ }^{*}$ Corresponding author.
} 


\section{Introduction}

According to the World Health Organization (WHO), 346 million people worldwide have diabetes [1]. The nationwide prevalence of diabetes in Argentina now tops 8.5\%, and is as high as $11.9 \%$ [2]. Type 2 diabetes mellitus (T2DM) accounts for almost $90 \%$ of all cases of diabetes in adults worldwide.

T2DM is characterized by a cluster of metabolic dysfunctions and cardiovascular risk factors, such as obesity, insulin resistance, dyslipidemia, atherosclerosis, hypertension, prothrombotic state, and endothelial dysfunction collectively known as the metabolic syndrome [3]. Environmental factors (e.g., obesity and sedentary lifestyles) give rise to T2DM [4].

It is well-known that high LDL-cholesterol (LDL-c) and triglycerides (TG) levels and low HDL-cholesterol (HDL-c) levels are strong predictable factors for cardiovascular events [5]. Thus, a dysregulation of metabolic homeostasis, together with an inadequate diet and lifestyle habits leads to alterations in lipid and lipoprotein profiles. The exact cause of dyslipidemia is not known. Genetics plays an important role on lipid homeostasis.

Many genes are involved in the regulation of exogenous and endogenous TGs [6] [7]. Some of the best described gene products act during intestinal absorption of dietary fat [fatty acid-binding protein-2 (FABP-2)] and the storage of excess free fatty acids [peroxisome proliferator-activated receptor $\gamma$ (PPAR- $\gamma$ )]. The occurrence of genetic polymorphisms in genes of molecules is strictly involved in regulation of fatty acid uptake and $\beta$-oxidation can have influence on lipid homeostasis, acting as risk factors for metabolic disturbances [8].

Peroxisome proliferator-activated receptors (PPARs) are nuclear receptors involved in the regulation of several biochemical pathways such as lipid and carbohydrate metabolism, lipoprotein synthesis, adipogenesis and insulin sensitivity [9] [10]. PPAR- $\gamma$ is a transcription factor with a key role in adipogenesis and insulin sensitization [11]. Frequent mutations in the PPAR- $\gamma$ gene have been described to be associated with obesity and diabetes-related phenotypes [12]-[14]. The common structural polymorphism with a proline (Pro) to alanine (Ala) substitution has been identified as a functional variant. Compared with the Pro allele, the Ala allele associates with reduced activity of PPAR- $\gamma$ [12]. This polymorphism was extensively investigated for association with obesity and type 2 diabetes and is considered to be one of the best replicated genetic risk factors of common type 2 diabetes, carrying the Ala variant being protective against type 2 diabetes [15]-[17].

Absorption of fatty acids (FA) across the intestinal mucosa, especially long-chain FA, is carried out by the intestinal FA-binding protein (FABP) encoded by the FABP-2 gene [18]. A polymorphism at codon 54 of the FABP-2 gene, changing alanine to threonine (Ala54Thr), increases the affinity of intestinal FABP for long-chain FA [19]. In subjects without diabetes, the presence of the Ala54Thr polymorphism has been associated with increases in serum postprandial lipids [20]-[23]. Patients with type 2 diabetes, in addition to frequently exhibiting increased serum fasting triglycerides and decreased high-density lipoprotein cholesterol, also have increased postprandial serum triglycerides [24].

The purpose of the present study was to evaluate the association between specific SNPs and haplotypes of the FABP-2 and PPAR- $\gamma$ genes with T2DM and lipid profile in the Santa Rosa del Conlara populations, San Luis, Argentina.

\section{Materials and Methods}

\subsection{Study Population}

The present study was carried out in accordance to the guidelines of the Helsinki Declaration. A total of 192 volunteers (100 patients with type 2 diabetes and 92 healthy age-matched controls) participated in this investigation. Criteria published by the Report of the Committee on the Classification and Diagnostic Criteria of Diabetes Mellitus, were used to diagnose Type 2 Diabetes Mellitus [25]. These patients reside in Santa Rosa del Conlara, San Luis, Argentina. The protocol for this study was approved by the local Institutional Review Board, and a written informed consent was obtained from each patient to be enrolled. Exclusion criteria included renal, hepatic or cerebrovascular disorders or endocrinal disorders, females on estrogen therapy and chronic disorders, as well as the use of lipid-lowering drugs, which can affect glucose metabolism and/or increase insulin resistance. 


\subsection{Anthropometric and Clinical Data}

For each subject enrolled, were sized height (meters) and weight (Kg) measurements. Height and weight were measured to the nearest $0.5 \mathrm{~cm}$ and $0.1 \mathrm{Kg}$, respectively. The body mass index (BMI) was calculated as weight divided by height squared $\left(\mathrm{Kg} / \mathrm{m}^{2}\right)$.

\subsection{Blood Sampling}

Blood samples were obtained from patients that had fasted overnight for a minimum of $12 \mathrm{~h}$. Blood was collected in tubes containing $0.1 \%$ EDTA. Plasma and blood cells were separated by centrifugation at $2400 \mathrm{rpm}$ for $20 \mathrm{~min}$ at room temperature. Plasma and packed blood cells were aliquoted and stored at $-20^{\circ} \mathrm{C}$ until use.

\subsection{Biochemical Measurement}

Fasting plasma glucose (FPG) was measured by using a glucose oxidase method with a commercial enzymatic kit (Wiener Laboratories, Rosario, Argentina). Glycated hemoglobin (HbA1c) concentration was measured with a coupled ionic-exchange chromatography/spectrophotometric assay (BioSystems, Barcelona, Spain). Total cholesterol (TC), triglycerides (TG) and HDL-c concentrations were measured using commercial kits by following manufacturer's instructions (Wiener Laboratories). Low density lipoprotein-cholesterol (LDL-c) was calculated with the Friedewald formula: LDL-c $=$ total cholesterol $(\mathrm{mg} / \mathrm{dL})-\mathrm{HDL}-\mathrm{c}(\mathrm{mg} / \mathrm{dL})-$ triglycerides $(\mathrm{mg} / \mathrm{dL}) / 5$ [26].

\subsection{Definitions}

The criteria for lipid and lipoprotein levels were according to the National Cholesterol Education Program [27]. Participants were diagnosed with dyslipidemia if they had one or more of the following criteria: a plasma concentration of TC of $\geq 6.24 \mathrm{mmol} / \mathrm{L}$ ( $\geq 240 \mathrm{mg} / \mathrm{dL}$ ), plasma concentration of TG $\geq 2.26 \mathrm{mmol} / \mathrm{L}(\geq 198 \mathrm{mg} / \mathrm{dL}$ ); plasma concentration of HDL-c of $<1.04 \mathrm{mmol} / \mathrm{L}(<40 \mathrm{mg} / \mathrm{dL})$ for men or $<1.30 \mathrm{mmol} / \mathrm{L}(<50 \mathrm{mg} / \mathrm{dL})$ for women; and a plasma concentration of LDL-c $\geq 4.14 \mathrm{mmol} / \mathrm{L}(\geq 160 \mathrm{mg} / \mathrm{dL})$.

\subsection{Genotyping}

DNA was extracted from packed blood cells using the Qiagen QiAmp Mini Kit (Valencia, CA). PCR amplifications and genotype determinations were conducted as follows:

FABP-2 (Ala54Thr). Ala54Thr (G/A) in exon 2 of FABP2 (rs1799883). DNA was amplified in a total volume of $20 \mu \mathrm{l}$ containing $100 \mathrm{ng}$ of genomic DNA, 20 pmol of each primer and 1 unit of AmpliTaq Gold DNA polymerase (Perkin-Elmer, Waltham, MA). These reactions were performed in a buffer containing $1.5 \mathrm{mmol} / \mathrm{L}$ $\mathrm{MgCl}_{2}, 50 \mathrm{mmol} / \mathrm{L} \mathrm{KCl}, 20 \mathrm{mmol} / \mathrm{L}$ Tris-HCl (pH 8.4), and $200 \mathrm{pmol} / \mathrm{L}$ of each deoxynucleotide triphosphate. The primers were as follows: forward primer: 5'ACAGGTGTTAATATAGTGAAAAG3' and reverse primer: 5'TACCCTGAGTTCAGTTCCGTC3' [19]. The template DNA was denatured for 3 minutes at $95^{\circ} \mathrm{C}$ before undergoing 30 cycles of amplification. Each amplification cycle included: denaturation for 30 seconds at $95^{\circ} \mathrm{C}$, primer annealing for 30 seconds at $55^{\circ} \mathrm{C}$, and extension for 45 seconds at $72^{\circ} \mathrm{C}$; followed by a final extension at $72^{\circ} \mathrm{C}$ for 3 minutes. For Restriction Fragment Length Polymorphism (RFLP) analysis, $5 \mu$ l of PCR product were incubated with $0.4 \mu \mathrm{l}$ of enzyme $C f o I(10 \mathrm{U} / \mu \mathrm{l}$, Promega, Madison, WI) in a final volume of $10 \mu \mathrm{l}$ for 1 hour at $37^{\circ} \mathrm{C}$. The products were run on a $10 \%$ non-denaturing PAGE for 50 minutes at $110 \mathrm{~V}$. Bands were observed after Ethidium bromide staining and UV light exposure. Visualization of two DNA fragments of the CfoI treated amplicon at 99 and 81 bp indicates a G allele (Ala54—presence of the restriction site), whereas an intact 180 bp indicates an A allele (Thr54-absence of the restriction site) (Figure 1).

PPAR- $\gamma$ (Pro12Ala). The PPAR- $\gamma$ polymorphism (rs1801282) Pro12Ala (C/G) was analyzed by Tetra Primer AMRS-PCR [28]. Two pairs of primers were used, one which amplifies a fragment of $553 \mathrm{bp}$, common to both alleles (outer primers: forward 5'AGACAGTGTGGCAATATTTTCCCTGTAA3' and reverse 5'GGTTC TGAACATGTTTTTAAATGAACGC3' and another pair specific for the SNP (inner primers): forward 5'GAAACTCTGGGAGATTCTCCTATTGTCC3' for the C allele (Pro12) and reverse 5'GTATCAGTGA AGGAATCGC TTTCAGC3' for the G allele (Ala12). Nucleotide sequence and SNP details were obtained from NCBI website (http://www.ncbi.nlm.nih.gob). The primers were designed "in silico" in a free access web 


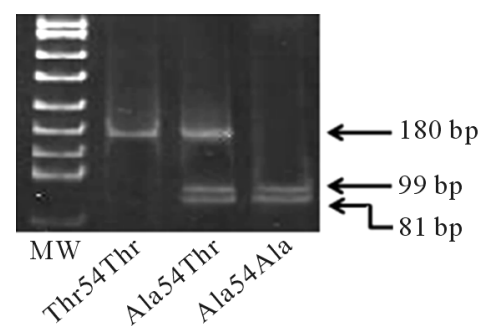

(a)

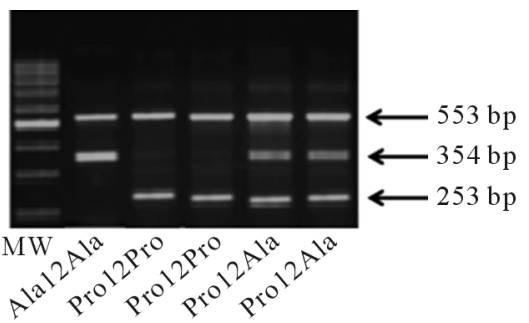

(b)

Figure 1. Representative gels of polymorphisms. (a) PCR-RFLP non-denaturing PAGE gel after digestion with $C f o I$ enzyme. The 180 bp band corresponds to the $\mathrm{G}$ allele (Ala) and the 99 and 81 bp bands correspond to the A allele (Thr) of the FABP2 gene; (b) Results of PPAR- $\gamma$ genotyping by Tetra Primer ARMS-PCR. The 553 bp band is the product of the outer primers, the $354 \mathrm{bp}$ band, of an outer primer and the inner primer for allele G (Ala) and the $253 \mathrm{bp}$ band, of the other outer primer and the inner primer for the $\mathrm{C}$ allele (Pro).

(http://cedar.genetics.soton.ac.uk) and then checked for specificity (http://blast.ncbi.nlm.nih.gov/Blast.cgi). Each PCR reaction was carried out in a total volume of $35 \mu \mathrm{L}$, containing $200 \mathrm{ng}$ of template DNA, 10 pmol of each inner primer, 1 pmol of each outer primer (1:10 ratio of outer to inner primer), $200 \mu \mathrm{M} \mathrm{dNTPs,} 2.5 \mathrm{mM} \mathrm{MgCl}$, $1 \times$ buffer, and 1 unit of AmpliTaq Gold DNA polymerase (Perkin-Elmer). The template DNA was denatured for 3 minutes at $95^{\circ} \mathrm{C}$ before undergoing 35 cycles of denaturation for 1 minute at $95^{\circ} \mathrm{C}$, primer annealing for 1 minute at $61^{\circ} \mathrm{C}$, and extension for 1 minute at $72^{\circ} \mathrm{C}$, and final extension at $72^{\circ} \mathrm{C}$ for 3 minutes. The resultant products obtained after PCR were separated by electrophoresis on $2.5 \%$ agarose gel containing GelRed. The image was visualized and photographed under UV transillumination. This resulted in 3 DNA fragments: one of $553 \mathrm{bp}$, one of $253 \mathrm{bp}$ for the $\mathrm{C}$ allele (Pro12) and one of $354 \mathrm{bp}$ for the G allele (Ala12) (Figure 1).

Randomly selected $20 \%$ of samples were re-genotyped for cross validating initial genotypes. In case of unclear genotyping results, the samples were repeated again in duplicates till clear genotype was available. Unclear genotyping results, even after repetition was excluded from the study. No genotyping error was observed during cross validation.

\subsection{Statistical Analysis}

Allele frequencies for SNPs were calculated by allele counting. Chi square test was used to check adjustment of the data to the Hardy-Weinberg equilibrium and to compare the allelic frequencies between controls and diabetic subjects. Comparison of allele frequencies and genotype distributions between case and control samples were done by Pearson's chi-square test. To analyze the association between genotypes, clinical and biochemical parameters a Student $t$-test was used when variables were continuous, whereas a Fisher's exact test was used for the categorical variables. Tests for association of each SNP or haplotype with T2DM were performed by using the SNPStat software. A p $<0.05$ was considered to be statically significant.

\section{Results}

\subsection{Subject Characteristics}

The anthropometric and clinical characteristics of the subjects in our study are shown in Table 1.

Table 2 provides detailed information of the selected SNPs, including their features, allelic variants, and the minor allele frequencies.

The frequencies of the Ala54Ala, Ala54Thr and Thr54Thr genotypes in the whole population of the FABP-2 polymorphism were $47.92 \%, 44.79 \%$ and $7.29 \%$, respectively, while the frequencies of Pro12Pro, Pro12Ala and Ala12Ala genotypes of the PPAR- $\gamma$ polymorphism were $66.67 \%, 27.08 \%$ and $6.25 \%$, respectively. The distribution and the allele frequency of the 2 polymorphisms followed the Hardy-Weinberg equilibrium.

\subsection{Inheritance Model}

When genotypes of FABP-2 were associated with T2DM according to all possible genetic models, no association of FABP-2 Ala54Thr polymorphism was found with T2DM according to any genetic model used (Table 3). 
Table 1. General characteristics of the studied subjects.

\begin{tabular}{|c|c|c|c|}
\hline & Control subjects $(n=92)$ & Diabetic subjects $(n=100)$ & $\mathrm{p}$ \\
\hline Age (years) & $55.45 \pm 12.16$ & $59.12 \pm 8.41$ & 0.1808 \\
\hline BMI $\left(\mathrm{kg} / \mathrm{m}^{2}\right)$ & $27.11 \pm 5.31$ & $33.35 \pm 8.70$ & $<0.0001$ \\
\hline FPG (mg/dL) & $87.52 \pm 15.65$ & $209.13 \pm 125.24$ & $<0.0001$ \\
\hline HbA1c (\%) & $5.41 \pm 0.66$ & $8.78 \pm 2.95$ & $<0.0001$ \\
\hline TC (mg/dL) & $197.93 \pm 28.74$ & $257.84 \pm 61.18$ & $<0.0001$ \\
\hline HDL-c (mg/dL) & $44.87 \pm 5.49$ & $39.34 \pm 6.94$ & 0.0093 \\
\hline LDL-c (mg/dL) & $113.98 \pm 31.27$ & $140.12 \pm 49.50$ & 0.0023 \\
\hline TG (mg/dL) & $154.52 \pm 53.25$ & $250.74 \pm 86.89$ & 0.0001 \\
\hline
\end{tabular}

Data are shown as mean \pm SD. Abbreviations used: BMI, body mass index; FPG, fasting plasma glucose; HbA1c, glycated hemoglobin; TC, total cholesterol; HDL, high density lipoprotein; LDL, low density lipoprotein; TG, triglycerides.

Table 2. Description of the selected SNPs for FABP-2 and PPAR- $\gamma$ genes.

\begin{tabular}{cccccc}
\hline SNP ID & Chromosome & Position & Exon/Intron & Substitution & $\begin{array}{c}\text { Functional } \\
\text { Consequence }\end{array}$ \\
\hline FABP-2 rs1799883 & 4 & 120241902 & Exon 2 & G/A & Missense \\
PPAR- $\gamma$ rs1801282 & 3 & 12393125 & Exon A1 & C/G & Missense \\
\hline
\end{tabular}

${ }^{\mathrm{a}} \mathrm{MAF}$ in the total group of this study. MAF, minor allele frequency; SNP, single nucleotide polymorphism.

Table 3. Frequencies of FABP2 genotypes according to Type 2 Diabetes Mellitus.

\begin{tabular}{|c|c|c|c|c|c|}
\hline Model $^{\mathrm{a}}$ & Genotype $^{\mathrm{b}}$ & $\begin{array}{c}\text { Control subjects } \\
n(\%)^{\mathrm{c}}\end{array}$ & $\begin{array}{c}\text { Diabetic subjects } \\
n(\%)^{\mathrm{c}}\end{array}$ & $\mathrm{p}$ & Hom OR ${ }^{d}(95 \%$ CI $)$ \\
\hline \multirow{3}{*}{ Codominant } & AlaAla & $42(45.6)$ & $50(50.0)$ & \multirow{3}{*}{0.31} & 1 \\
\hline & AlaThr & $40(43.5)$ & $46(46.0)$ & & $0.94(0.41-2.20)$ \\
\hline & ThrThr & $10(10.9)$ & $4(4.0)$ & & $0.27(0.05-1.60)$ \\
\hline \multirow{2}{*}{ Dominant } & AlaAla & $42(45.6)$ & $50(50.0)$ & \multirow{2}{*}{0.60} & 1 \\
\hline & AlaThr/ThrThr & $50(54.4)$ & $50(50.0)$ & & $0.80(0.36-1.81)$ \\
\hline \multirow{2}{*}{ Recessive } & AlaAla/AlaThr & $82(89.19$ & $96(96.0)$ & \multirow{2}{*}{0.12} & 1 \\
\hline & ThrThr & $10(10.9)$ & $4(4.0)$ & & $0.28(0.05-1.56)$ \\
\hline \multirow{2}{*}{ Overdominant } & AlaAla/ThrThr & $52(56.5)$ & $54(54.0)$ & \multirow{2}{*}{0.80} & 1 \\
\hline & AlaThr & $40(43.5)$ & $46(46.0)$ & & $1.11(0.49-2.51)$ \\
\hline Log-additive & - & - & - & 0.29 & $0.70(0.36-1.36)$ \\
\hline
\end{tabular}

${ }^{\mathrm{a}}$ Inherintance models; ${ }^{\mathrm{b}}$ Genotypes and their groupings for the FABP-2 polymorfism (rs1799883); ${ }^{\mathrm{c}}$ Genotype frequency expressed as number of individuals, $\mathrm{n}$-values in parentheses indicate percentage; ${ }^{\mathrm{d}} \mathrm{OR}=$ odds ratio, $95 \% \mathrm{CI}=95 \%$ confidence interval.

For the PPAR- $\gamma$ polymorphism, no association was found with T2DM according to any genetic model used (Table 4).

As shown in Table 5, the frequency of the rare Thr54 allele of the FABP-2 polymorphism in control (0.33) was not different from the frequency in T2DM (0.27), whereas the frequency of the rare Ala12 allele of the PPAR $-\gamma$ polymorphism in control was different from the frequency in T2DM $(0.26$ and 0.14 , respectively; $\mathrm{p}=$ $0.0031)$.

Due to very low frequencies of the homocygotes genotypes, the Thr54Thr of the FABP-2 and the Ala12Ala of 
Table 4. Frequencies of PPAR- $\gamma$ genotypes according to Type 2 Diabetes Mellitus.

\begin{tabular}{|c|c|c|c|c|c|}
\hline Model $^{\mathrm{a}}$ & Genotype $^{\mathrm{b}}$ & $\begin{array}{c}\text { Control subjects } \\
n(\%)^{\mathrm{c}}\end{array}$ & $\begin{array}{c}\text { Diabetic subjects } \\
\mathrm{n}(\%)^{\mathrm{c}}\end{array}$ & $\mathrm{p}$ & Hom OR ${ }^{\mathrm{d}}(95 \% \mathrm{CI})$ \\
\hline \multirow{3}{*}{ Codominant } & ProPro & $52(56.5)$ & $76(76.0)$ & \multirow{3}{*}{0.19} & 1 \\
\hline & ProAla & $32(34.8)$ & $20(20.0)$ & & $0.46(0.18-1.18)$ \\
\hline & AlaAla & $8(8.7)$ & $4(4.0)$ & & $0.38(0.06-2.25)$ \\
\hline \multirow{2}{*}{ Dominant } & ProPro & $52(56.5)$ & $76(76.0)$ & \multirow{2}{*}{0.069} & \multirow{2}{*}{$0.44(0.18-1.08)$} \\
\hline & ProAla/AlaAla & $40(43.5)$ & $24(24.0)$ & & \\
\hline \multirow{2}{*}{ Reccesive } & ProPro/ProAla & $84(91.3)$ & $96(96.0)$ & \multirow{2}{*}{0.41} & \multirow{2}{*}{$0.48(0.08-2.83)$} \\
\hline & AlaAla & $8(8.7)$ & $4(4.0)$ & & \\
\hline \multirow{2}{*}{ Overdominant } & ProPro/AlaAla & $60(65.2)$ & $80(80.0)$ & \multirow{2}{*}{0.14} & 1 \\
\hline & ProAla & $32(34.8)$ & $20(20.0)$ & & $0.50(0.20-1.28)$ \\
\hline Log-additive & - & - & - & 0.078 & $0.53(0.26-1.09)$ \\
\hline
\end{tabular}

${ }^{\mathrm{a}}$ Inherintance models; ${ }^{\mathrm{b}}$ Genotypes and their groupings for the PPAR- $\gamma$ polymorfism (rs1801282); ${ }^{\mathrm{c}}$ Genotype frequency expressed as number of individuals, $\mathrm{n}$-values in parentheses indicate percentage; ${ }^{\mathrm{O}} \mathrm{OR}=$ odds ratio, $95 \% \mathrm{CI}=95 \%$ confidence interval.

Table 5. Genotypes and allele frequencies for the FABP-2 and PPAR- $\gamma$ polymorphisms in control and Type 2 Diabetes Mellitus.

\begin{tabular}{|c|c|c|c|c|c|c|c|}
\hline SNP & Allele & $\begin{array}{c}\text { Control } \\
\text { subjects } \mathrm{F}^{\mathrm{a}}\end{array}$ & $\begin{array}{l}\text { Duabetic } \\
\text { subjects } F^{a}\end{array}$ & Genotype & $\begin{array}{c}\text { Control } \\
\text { subjects } \\
\text { n (\%) }\end{array}$ & $\begin{array}{c}\text { Diabetic } \\
\text { subjects } \\
\text { n (\%) }\end{array}$ & $\begin{array}{c}\text { Allelic OR }^{\mathrm{C}} \\
(95 \% \mathrm{CI})\end{array}$ \\
\hline \multirow{3}{*}{$\begin{array}{c}\text { rs1799883 } \\
\text { (FABP-2) }\end{array}$} & Ala & 0.67 & 0.73 & AlaAla & 42 (45.65) & $50(50.0)$ & \multirow{3}{*}{$\begin{array}{c}\mathrm{p}=0.263 \\
0.76 \\
(0.76-1.18)\end{array}$} \\
\hline & & & & AlaThr & $40(43.48)$ & $46(46.0)$ & \\
\hline & Thr & 0.33 & 0.27 & ThrThr & $10(10.87)$ & $4(4.0)$ & \\
\hline \multirow{3}{*}{$\begin{array}{c}\text { rs1801282 } \\
\text { (PPAR- } \gamma \text { ) }\end{array}$} & Pro & 0.74 & 0.86 & ProPro & $52(56.52)$ & $76(76.0)$ & \multirow{3}{*}{$\begin{array}{c}\mathrm{p}=0.0031 \\
0.45 \\
(0.27-0.76)\end{array}$} \\
\hline & & & & ProAla & $32(34.78)$ & $20(20.0)$ & \\
\hline & Ala & 0.26 & 0.14 & AlaAla & 8 (8.69) & $4(4.0)$ & \\
\hline
\end{tabular}

${ }^{\mathrm{a}} \mathrm{F}=$ Allele frequency; ${ }^{\mathrm{b}} \mathrm{Genotype}$ frequency expressed as number of individuals, $\mathrm{n}$-values in parentheses indicate percentage; ${ }^{\mathrm{c}} \mathrm{OR}=$ odds ratio, $95 \%$ $\mathrm{CI}=95 \%$ confidence interval.

the PPAR- $\gamma$ were analyzed in the same category as the corresponding heterozygotic genotype, namely as non Ala54Ala (Thr carriers) and non Pro12Pro (Ala carriers), respectively.

The anthropometric and clinical characteristics of controls and T2DM for the Ala54Thr polymorphism (rs1799883) of the FABP-2 gene are shown in Table 6. There were no differences between control patients with Ala54Ala and non-Ala54Ala genotypes, whereas in T2DM the presence of the non-Ala54Ala genotype was associated with an increase in BMI compared with the Ala54Ala homocygotes.

The comparison of the anthropometric and clinical characteristics by the polymorphism PPAR- $\gamma$ (rs1801282) in controls and T2DM are shown in Table 7. No statistically significant associations with anthropometric and clinical characteristics were observed for this polymorphism in controls. However, in diabetic subjects, there were statistically significant differences in total cholesterol (TC) values, with carriers of the Ala12 allele (non Pro12Pro) having higher TC values than Pro12 homozygotes $(\mathrm{p}=0.0056)$.

\subsection{Haplotype Analyses of PPAR- $\gamma$ and FABP-2 SNPs}

To further evaluate the role of these SNPs with T2DM, we sought to determine whether these SNPs demonstrated any evidence of association when examined together by performing haplotype analysis.

The two SNPs (rs1799883 and rs1801282) defined four haplotypes. Estimated frequencies of the four common haplotypes with respect to the presence of T2DM are shown in Table 8. The haplotypes that consisted of two common alleles at SNP rs1799883 and rs1801282 (Ala-Pro) were more frequent in T2DM subjects than in control subjects. Conversely, the haplotypes carrying one of the minor alleles at SNP rs7903146 or rs12255372 
Table 6. Anthropometric and clinical characteristics by the FABP-2 polymorphism in controls and Type 2 Diabetes Mellitus.

\begin{tabular}{rccccccc}
\hline & \multicolumn{2}{c}{ Control subjects $(\mathrm{n}=92)$} & & \multicolumn{2}{c}{ Diabetic subjects $(\mathrm{n}=100)$} & $\mathrm{p}$ \\
\cline { 2 - 3 } & Ala54Ala & Non Ala54Ala & & & Ala54Ala & Non Ala54Ala & \\
\hline BMI $\left(\mathrm{kg} / \mathrm{m}^{2}\right)$ & $27.67 \pm 4.75$ & $26.64 \pm 5.79$ & & 0.2948 & $30.12 \pm 5.28$ & $36.59 \pm 10.23$ & 0.0161 \\
FPG (mg/dL) & $90.10 \pm 15.01$ & $85.36 \pm 16.15$ & 0.4203 & $218.84 \pm 148.43$ & $198.57 \pm 96.19$ & 0.9506 \\
HbA1c (\%) & $5.29 \pm 0.61$ & $5.54 \pm 0.72$ & 0.3960 & $7.28 \pm 2.06$ & $9.13 \pm 3.06$ & 0.2263 \\
TG (mg/dL) & $167.14 \pm 58.73$ & $143.92 \pm 46.76$ & 0.1637 & $246.16 \pm 80.18$ & $255.32 \pm 94.57$ & 0.7123 \\
TC (mg/dL) & $214.14 \pm 41.84$ & $201.92 \pm 33.95$ & 0.3748 & $244.92 \pm 78.87$ & $235.92 \pm 72.60$ & 0.8158 \\
HDL-c (mg/dL) & $44.86 \pm 5.31$ & $44.88 \pm 5.75$ & 0.9824 & $38.12 \pm 6.02$ & $40.56 \pm 7.21$ & 0.346 \\
LDL-c (mg/dL) & $120.05 \pm 35.97$ & $108.88 \pm 26.37$ & 0.1402 & $147.28 \pm 51.16$ & $132.96 \pm 47.73$ & 0.1301 \\
\hline
\end{tabular}

Data are shown as mean \pm SD. Abbreviations used: BMI, body mass index; FPG, fasting plasma glucose; HbA1c, glycated hemoglobin; TC, total cholesterol; HDL, high density lipoprotein; LDL, low density lipoprotein; TG, triglycerides.

Table 7. Anthropometric and clinical characteristics by the PPAR- $\gamma$ polymorphism in controls and Type 2 Diabetes Mellitus.

\begin{tabular}{|c|c|c|c|c|c|c|}
\hline & \multicolumn{2}{|c|}{ Control subjects $(\mathrm{n}=92)$} & \multirow{2}{*}{$\mathrm{p}$} & \multicolumn{2}{|c|}{ Diabetic subjects $(n=100)$} & \multirow{2}{*}{$\mathrm{p}$} \\
\hline & Pro12Pro & Non Pro12Pro & & Pro12Pro & Non Pro12Pro & \\
\hline $\operatorname{BMI}\left(\mathrm{kg} / \mathrm{m}^{2}\right)$ & $25.99 \pm 4.86$ & $28.56 \pm 5.63$ & 0.1106 & $33.59 \pm 9.03$ & $32.58 \pm 7.85$ & 0.8469 \\
\hline FPG (mg/dL) & $82.92 \pm 14.76$ & $93.50 \pm 15.06$ & 0.0198 & $202.46 \pm 126.12$ & $231.55 \pm 125.48$ & 0.4692 \\
\hline HbA1c (\%) & $5.22 \pm 0.60$ & $5.66 \pm 0.69$ & 0.1642 & $9.32 \pm 2.47$ & $8.61 \pm 3.14$ & 0.3634 \\
\hline TG (mg/dL) & $143.00 \pm 44.56$ & $169.50 \pm 60.72$ & 0.1457 & $243.55 \pm 85.68$ & $273.50 \pm 90.55$ & 0.2705 \\
\hline TC (mg/dL) & $191.96 \pm 24.70$ & $205.70 \pm 32.27$ & 0.1702 & $244.92 \pm 54.92$ & $298.75 \pm 64.21$ & 0.0056 \\
\hline HDL-c (mg/dL) & $44.08 \pm 4.97$ & $45.90 \pm 6.08$ & 0.2713 & $39.79 \pm 7.15$ & $37.92 \pm 6.33$ & 0.3627 \\
\hline LDL-c (mg/dL) & $114.85 \pm 35.10$ & $112.85 \pm 26.30$ & 0.3847 & $133.21 \pm 47.29$ & $162.00 \pm 52.00$ & 0.0709 \\
\hline
\end{tabular}

Data are shown as mean \pm SD. Abbreviations used: BMI, body mass index; FPG, fasting plasma glucose; HbA1c, glycated hemoglobin; TC, total cholesterol; HDL, high density lipoprotein; LDL, low density lipoprotein; TG, triglycerides.

Table 8. Estimated frequency of common haplotypes and their associations with Type 2 Diabetes Mellitus.

\begin{tabular}{|c|c|c|c|c|c|}
\hline \multicolumn{2}{|c|}{ Haplotype } & \multirow[b]{2}{*}{ Control subjects $\mathrm{F}^{\mathrm{a}}$} & \multirow[b]{2}{*}{ Diabetic subjects $F^{a}$} & \multirow[b]{2}{*}{ OR $(95 \% \text { CI })^{\mathrm{b}}$} & \multirow[b]{2}{*}{$\mathrm{p}$} \\
\hline $\begin{array}{l}\text { Ala54Thr } \\
\text { (rs1799883) }\end{array}$ & $\begin{array}{l}\text { Pro12Ala } \\
\text { (rs1801282) }\end{array}$ & & & & \\
\hline Ala & Pro & 0.4712 & 0.6831 & 1 & - \\
\hline Ala & Ala & 0.2028 & 0.0469 & $0.14(0.04-0.53)$ & 0.0045 \\
\hline Thr & Pro & 0.268 & 0.1769 & $0.42(0.18-0.97)$ & 0.045 \\
\hline Thr & Ala & 0.0581 & 0.0931 & $1.31(0.30-5.73)$ & 0.72 \\
\hline
\end{tabular}

${ }^{\mathrm{a}} \mathrm{F}$ = haplotype frequency; ${ }^{\mathrm{b}} \mathrm{OR}=$ odds ratio, 95\% CI = 95\% confidence interval were calculated by comparing each haplotype to the more common haplotype.

were more frequent in the control group.

We further examined the potential associations between dyslipidemia and haplotypes of rs1799883 and rs1801282 in T2DM patients. Haplotype association analysis showed the associations between ThrPro haplotype and TG levels $(\mathrm{OR}=2.520 ; 95 \% \mathrm{CI}=1.139-5.575 ; \mathrm{p}=0.027)$ and between ThrPro haplotype and TC and LDL-c levels when compared to AlaPro haplotype (difference $=0.175,95 \% \mathrm{CI}=0068-0.499, \mathrm{p}<0.0001$; difference $=0.052,95 \% \mathrm{CI}=0.017-0.158, \mathrm{p}<0.0001$, respectively; Table 9). 
Table 9. Haplotypes of FABP-2 rs1799883 and PPAR- $\gamma$ rs1801282 polymorphisms and association with dyslipidemia in diabetic patients.

\begin{tabular}{|c|c|c|c|c|c|}
\hline & $\begin{array}{c}\text { Ala54Thr } \\
\text { (rs1799883) }\end{array}$ & $\begin{array}{c}\text { Pro12Ala } \\
\text { (rs1801282) }\end{array}$ & $\begin{array}{l}\text { Haplotype } \\
\text { Frequency }\end{array}$ & OR $(95 \% \mathrm{CI})$ & $\mathrm{p}$ \\
\hline \multirow{4}{*}{$\mathrm{TC}$} & Ala & Pro & 0.570 & 1 & \\
\hline & Ala & Ala & 0.055 & $0.272(0.053-1.396)$ & 0.146 \\
\hline & Thr & Pro & 0.259 & $0.175(0.068-0.499)$ & $<0.0001$ \\
\hline & Thr & Ala & 0.111 & $0.544(0.209-1.414)$ & 0.2368 \\
\hline \multirow{4}{*}{ LDL-C } & Ala & Pro & 0.488 & 1 & \\
\hline & Ala & Ala & 0.036 & $0.680(0.155-2.983)$ & 0.693 \\
\hline & Thr & Pro & 0.360 & $0.052(0.017-0.158)$ & $<0.0001$ \\
\hline & Thr & Ala & 0.097 & $0.612(0.233-1.611)$ & 0.312 \\
\hline \multirow{4}{*}{ TG } & Ala & Pro & 0.701 & 1 & \\
\hline & Ala & Ala & 0.052 & $0.209(0.012-3.732)$ & 0.207 \\
\hline & Thr & Pro & 0.130 & $2.520(1.139-5.575)$ & 0.027 \\
\hline & Thr & Ala & 0.017 & $0.400(0.08-1.822)$ & 0.371 \\
\hline
\end{tabular}

OR = odds ratio, 95\% CI = 95\% confidence interval were calculated by comparing each haplotype to the more common haplotype.

\section{Discussion}

The FABP-2 gene has been proposed as a candidate gene for diabetes because the protein is involved in fatty acids absorption and metabolism and may, therefore, affect insulin sensitivity and glucose metabolism. The most extensively studied variant is the missense Ala54Thr variation, which is common in diverse populations and results in increased fatty acid absorption in vivo.

There are no previous reports about the prevalence of the Thr54 FABP-2 variant in our region. In the sample tested, the observed Thr54 frequency (0.30) is similar to that reported in most populations [29], but the Thr54 allele frequencies were slightly higher than those reported in different European countries (0.276) [30]. It must be stated that the study group is mostly of colonizing European populations origin, mainly from Italy and Spain, and a $2 \%$ of this group population have aboriginal ethnic ancestries suggesting that the original European allele frequency in this area has not conserved. The fact that the polymorphism is in Hardy Weinberg equilibrium suggests that there is no significant natural selection pressure acting against individuals with the Thr54 FABP-2 variant living in Santa Rosa del Conlara, San Luis, Argentina. Other South American frequency analysis of Thr54 were reported by an Argentinean group, who observed a Thr54 frequency of 0.277 in subjects belonged to an ongoing Regional Cardiovascular Prevention Program (RCP program), organized by the Public Health Care Program for Government Employees (OSEP) of Mendoza (Argentina) [31].

In our sample of patients with type 2 diabetes, the frequency of the Thr54 allele was 0.27 who was similar to a Brazilian study that reported a Thr54 frequency $=0.25$ in diabetes type 2 individuals [32]. In the other hand, the frequency of the Thr54Thr genotype was $4.00 \%$ in our T2DM patients, whereas the frequency of the Thr54Thr genotype is $6.25 \%$ in Brazilian diabetic patients [32] and 4.00\% in American patients with type 2 diabetes [33].

To investigate the hypothesis that defects in the FABP-2 gene could be associated with type 2 diabetes mellitus and their related metabolic traits, we studied the effects of Ala54Thr variant in Santa Rosa del Conlara population.

Studies examining the association of FABP-2 A54T polymorphism with T2DM are contradictory. Several studies have reported the association between the Ala54Thr polymorphism of FABP-2 with insulin resistance and diabetes [19] [34]-[39]. Other studies have reported no association between this polymorphism and T2DM [19] [31] [40]-[45]. There are differences among studies on the design as well as the genetic models used to assess associations of FABP-2 Ala54Thr polymorphism with this disease. We looked at the association of FABP-2 Ala54Thr polymorphism with T2DM according to all possible genetic models. No association of FABP-2 
Ala54Thr polymorphism was found with T2DM according to any genetic model used, a finding shared by other studies that examined such an association [46].

In the present study we have not found differences in glycemia, HbA1c and serum lipids between FABP-2 genotype groups although significant differences in BMI were attained in Diabetic group carriers of the Thr allele. The results from studies published on the association of FABP-2 Ala54Thr polymorphism with body mass index (BMI) are conflicting, but the conclusions from the meta analysis carried out by Zhao et al. [47] showed no evidence that the FABP-2 Ala54Thr polymorphism is significantly associated with BMI in overall populations. It is possible that carriers of the Thr allele in our T2DM patients confers some degree of susceptibility to obesity, associated with an influence of gene/environment interactions such as diet, exercise, body composition and life style modification [46] [48].

In this study, the frequency of the Ala allele of the PPAR- $\gamma$ polymorphism in participants with and without diabetes were $1.4 \%$ and $2.6 \%$, respectively. The frequency of the Ala allele appears to vary greatly by the genetic background of the populations [49]. In general, the frequency of the Ala allele has been reported to be highest in Caucasians [50]. Variations in the allelic frequency of the Pro12Ala polymorphism across different ethnicities and regions could be attributed to genetic variations and to different environmental and lifestyle exposures [51].

We found that the Ala allele of the Pro12Ala polymorphism was associated with a significantly lower risk of type 2 diabetes in our population. Consistent with our results, Altshuler et al. [15] found a significant decrease in diabetes risk associated with the Ala allele in a Caucasian population. In Finnish subjects, the Ala12 variant of the PPAR- $\gamma$ gene was associated with protection against T2DM [51]. Meta-analyses [4] [52] also showed a significant effect of the Ala allele on lower development of T2DM.

In the present study we have not found differences in glycemia, HbA1c, LDL-c, HDL-c, TG and BMI between PPAR- $\gamma$ genotype groups although significant differences in TC were attained in Diabetic group carriers of the Ala allele. Mori et al. [53] found that carriers of the Ala12 allele had higher total cholesterol than those without the allele among diabetic subjects. One study in an Italian population [54] found that this polymorphism was not associated with anthropometrical and biochemical parameters among normoglycemic and diabetic subjects. Ethnic differences, study design, and effects of BMI may contribute to discrepancies in these results.

The substitution from proline to alanine at codon 12 has been shown to regulate transcriptional activity [12] [55]. Because this polymorphism is next to the amino-terminus of the protein in the ligand-independent activation domain, its activity is induced by insulin through phosphorylation. Alanine helps the formation of helices, but proline prevents it. Thus, it is possible that this amino acid change affects the structure and consequently the function of the protein [49]. The alanine isoform contributes to less efficient stimulation of PPAR- $\gamma$ target genes and predisposes people to reduce levels of adipose tissue mass accumulation. This in turn may improve insulin sensitivity. It is known that decreased insulin sensitivity plays an important role in the pathogenesis of type 2 diabetes.

Although abundant data on individual gene variants affecting lipid and lipoprotein metabolism are present in the literature, their usefulness for identifying individual profiles for T2DM risk and its altered lipid profile is fairly limited. This is attributable to the small effect that a single gene has, which in addition can vary depending on factors such as life style, environmental stimuli, and other genes.

Further, we aimed to investigate the haplotype association of the variant at the FABP-2 (rs1799883 polymorphisms) and PPAR- $\gamma$ (rs1801282) polymorphisms) locus with Type 2 Diabetes Mellitus and the characteristic dyslipidemia of this disease. Haplotype association analysis showed the associations between ThrPro haplotype and TG levels (OR $=2.520 ; 95 \% \mathrm{CI}=1.139-5.575 ; \mathrm{p}=0.027)$ and between ThrPro haplotype and TC and LDL-c levels when compared to AlaPro haplotype (difference $=0.175,95 \% \mathrm{CI}=0068-0.499$, $\mathrm{p}<0.0001$; difference $=0.052,95 \% \mathrm{CI}=0.017-0.158, \mathrm{p}<0.0001$, respectively; Table 9). There are no studies that associated haplotypes of these two polymorphisms with lipid metabolism alterations. So far, the haplotype analysis regarding rs1799883 and rs1801282 polymorphisms for dyslipidemia has not been reported yet.

Our study found that Thr-Pro haplotype of FABP-2 and PPAR- $\gamma$ was associated with dyslipidemia. PPAR- $\gamma$ plays an indispensible role in the regulation of adipocyte differentiation, lipid storage, glucose metabolism and the transcriptional regulation of a number of genes involved in these metabolic processes. The key target genes of PPAR- $\gamma$ include the fat-specific AP2 gene, LPL (lipoprotein lipase), fatty acid transport protein, fatty acid binding protein, ABC-A1 [ATP-binding cassette, sub-family A (ABC1), member 1] and so on [56].

We thought that rs1801282 polymorphisms (Pro12 alelle) may influence the receptor activity, the ability to 
transactivate responsive promoters and so on to regulate the key target genes of PPAR- $\gamma$ which could influence the lipid metabolism. But the specific biological mechanism needs to be further studied.

In the other hand, FABP-2 is involved in the transport and metabolism of saturated and unsaturated longchain fatty acids (FAs). The missense Ala54Thr variation results in increased activity. Thus, subjects with the Thr54 allele may increase intestinal absorption of cholesterol, and this is associated with the higher cholesterol and LDL cholesterol levels in those with Thr54 allele among diabetic.

\section{Conclusions}

In conclusion, our study has tested the gene-gene interaction between common polymorphisms within FABP-2 and PPAR- $\gamma$ gene and dyslipidemia based on haplotype analyses. These results may help to evaluate their haplotypes as being characterized as genetic risk factors for dyslipidemia in Type 2 Diabetes Mellitus.

In conclusion, we report that in T2DM the additive effects of Thr-Pro haplotype of FABP-2 and PPAR- $\gamma$ genes altered lipid metabolism.

\section{Acknowledgements}

This research was supported by grants from the Universidad Nacional de San Luis (MSO-9900). We are grateful to Dr. Roberto Lucero for recruiting the study subjects and coordinating data collection.

\section{Conflict of Interests}

The authors declare no conflict of interests with respect to the present paper.

\section{References}

[1] Scully, T. (2012) Diabetes in Numbers. Nature, 485, S2-S3. http://dx.doi.org/10.1038/485S2a

[2] Slimel, M.R., Coppolillo, F.E., Masi, J.D., Mendoza, S.M. and Tannuri, J. (2010) Epidemiology of Diabetes in Argentina. Avances en Diabetología, 26, 101-106. http://dx.doi.org/10.1016/S1134-3230(10)62006-6

[3] Gross, B. and Staels, B. (2007) PPAR Agonists: Multimodal Drugs for the Treatment of Type-2 Diabetes. Best Practice Research Clinical Endocrinology Metabolism, 21, 687-710. http://dx.doi.org/10.1016/j.beem.2007.09.004

[4] Gouda, H.N., Sagoo, G.S., Harding, A.H., Yates, J., Sandhu, M.S. and Higgins, J.P. (2010) The Association between the Peroxisome Proliferator-Activated Receptor-Gamma 2 (PPARG2) Pro12Ala Gene Variant and Type 2 Diabetes Mellitus: A HuGE Review and Meta-Analysis. American Journal of Epidemiology, 171, 645-655. http://dx.doi.org/10.1093/aje/kwp450

[5] Cullen, P. (2000) Evidence That Triglycerides Are an Independent Coronary Heart Disease Risk Factor. American Journal of Cardiology, 86, 943-949. http://dx.doi.org/10.1016/S0002-9149(00)01127-9

[6] Busch, C.P. and Hegele, R.A. (2000) Variation of Candidate Genes in Triglyceride Metabolism. Journal of Cardiovascular Risk, 7, 309-315.

[7] Ordovas, J.M. (2001) Genetics, Postprandial Lipemia and Obesity. Nutrition, Metabolism, Cardiovascular Diseases, 211, 118-133.

[8] Chen, E.S., Mazzotti, D.R., Furuya, T.K., Cendoroglo, M.S., Ramos, L.R., Araujo, L.Q., Burbano, R.R. and Smith Mde, A. (2010) Association of PPARalpha Gene Polymorphisms and Lipid Serum Levels in a Brazilian Elderly Population. Experimental and Molecular Pathology, 88, 197-201. http://dx.doi.org/10.1016/j.yexmp.2009.10.001

[9] Prieur, X., Coste, H. and Rodriguez, J.C. (2003) The Human Apolipoprotein AV Gene Is Regulated by Peroxisome Proliferator-Activated Receptor-Alpha and Contains a Novel Farnesoid X-Activated Receptor Response Element. The Journal of Biological Chemistry, 278, 25468-25480. http://dx.doi.org/10.1074/jbc.M301302200

[10] Yong, E.L., Li, J. and Liu, M.H. (2008) Single Gene Contributions: Genetic Variants of Peroxisome Proliferator-Activated Receptor (Isoforms Alpha, Beta/Delta and Gamma) and Mechanisms of Dyslipidemias. Current Opinion in Lipidology, 19, 106-112. http://dx.doi.org/10.1097/MOL.0b013e3282f64542

[11] Fajas, L., Debril, M.B. and Auwerx, J. (2001) PPAR Gamma: An Essential Role in Metabolic Control. Nutrition Metabolism and Cardiovascular Diseases, 11, 64-69.

[12] Deeb, S.S., Fajas, L., Nemoto, M., Pihlajamäki, J., Mykkänen, L., Kuusisto, J., Laakso, M., Fujimoto, W. and Auwerx, J.A. (1998) Pro12Ala Substitution in PPARgamma2 Associated with Decreased Receptor Activity, Lower Body Mass Index and Improved Insulin Sensitivity. Nature Genetics, 20, 284-287. http://dx.doi.org/10.1038/3099 
[13] Doney, A.S., Fischer, B., Cecil, J.E., Boylan, K., McGuigan, F.E., Ralston, S.H., Morris, A.D. and Palmer, C.N. (2004) Association of the Pro12Ala and C1431T Variants of PPARG and Their Haplotypes with Susceptibility to Type 2 Diabetes. Diabetologia, 47, 555-558. http://dx.doi.org/10.1007/s00125-003-1323-1

[14] Meirhaeghe, A., Fajas, L., Helbecque, N., Cottel, D., Lebel, P., Dallongeville, J., Deeb, S., Auwerx, J. and Amouyel, P. (1998) A Genetic Polymorphism of the Peroxisome Proliferator-Activated Receptor $\gamma$ Gene Influences Plasma Leptin Levels in Obese Humans. Human Molecular Genetics, 7, 435-440. http://dx.doi.org/10.1093/hmg/7.3.435

[15] Altshuler, D., Hirschhorn, J.N., Klannemark, M., Lindgren, C.M., Vohl, M.C., Nemesh, J., Lane, C.R., Schaffner, S.F., Bolk, S., Brewer, C., Tuomi, T., Gaudet, D., Hudson, T.J., Daly, M., Groop, L. and Lander, E.S. (2000) The Common PPARgamma Pro12Ala Polymorphism Is Associated with Decreased Risk of Type 2 Diabetes. Nature Genetics, 26, 76-80. http://dx.doi.org/10.1038/79216

[16] Lohmueller, K.E., Pearce, C.L., Pike, M., Lander, E.S. and Hirschhorn, J.N. (2003) Meta-Analysis of Genetic Association Studies Supports a Contribution of Common Variants to Susceptibility to Common Disease. Nature Genetics, 33, 177-182. http://dx.doi.org/10.1038/ng1071

[17] Tönjes, A., Scholz, M., Loeffler, M. and Stumvoll, M. (2006) Association of Pro12Ala Polymorphism in Peroxisome Proliferator-Activated Receptor Gamma with Pre-Diabetic Phenotypes: Meta-Analysis of 57 Studies on Nondiabetic Individuals. Diabetes Care, 29, 2489-2497. http://dx.doi.org/10.2337/dc06-0513

[18] Hegele, R.A. (1998) A Review of Intestinal Fatty Acid Binding Protein Gene Variation and the Plasma Lipoprotein Response to Dietary Components. Clinical Biochemistry, 31, 609-612. http://dx.doi.org/10.1016/S0009-9120(98)00078-2

[19] Baier, L.J., Sacchettini, J.C., Knowler, W.C., Eads, J., Paolisso, G., Tataranni, P.A., Mochizuki, H., Bennett, P.H., Bogardus, C. and Prochazka, M. (1995) An Amino Acid Substitution in the Human Intestinal Fatty Acid Binding Protein Is Associated with Increased Fatty Acid Binding, Increased Fat Oxidation and Insulin Resistance. Journal of Clinical Investigation, 95, 1281-1287. http://dx.doi.org/10.1172/JCI117778

[20] Agren, J.J., Valve, R., Vidgren, H., Laakso, M. and Uusitupa, M. (1998) Postprandial Lipemic Response Is Modified by the Polymorphism at Codon 54 of the Fatty Acid-Binding Protein 2 Gene. Arteriosclerosis, Thrombosis and Vascular Biology, 18, 1606-1610. http://dx.doi.org/10.1161/01.ATV.18.10.1606

[21] Agren, J.J., Vidgren, H.M., Valve, R.S., Laakso, M. and Uusitupa, M.I. (2001) Postprandial Responses of Individual Fatty Acids in Subjects Homozygous for the Threonine- or Alanine-Encoding Allele in Codon 54 of the Intestinal Fatty Acid Binding Protein 2 Gene. The American Journal of Clinical Nutrition, 73, 31-35.

[22] Dworatzek, P.D., Hegele, R.A. and Wolever, T.M. (2004) Postprandial Lipemia in Subjects with the Threonine 54 Variant of the Fatty Acid-Binding Protein 2 Gene Is Dependent on the Type of Fat Ingested. The American Journal of Clinical Nutrition, 79, 1110-1117.

[23] Lefevre, M., Lovejoy, J.C., Smith, S.R., Delany, J.P., Champagne, C., Most, M.M., Denkins, Y., de Jonge, L., Rood, J. and Bray, G.A. (2005) Comparison of the Acute Response to Meals Enriched with Cis- or Trans-Fatty Acids on Glucose and Lipids in Overweight Individuals with Differing FABP2 Genotypes. Metabolism, 54, 1652-1658. http://dx.doi.org/10.1016/j.metabol.2005.06.015

[24] Mero, N., Syvänne, M. and Taskinen, M.R. (1998) Postprandial Lipid Metabolism in Diabetes. Atherosclerosis, 141, S53-S55. http://dx.doi.org/10.1016/S0021-9150(98)00218-4

[25] Seino, Y., Nanjo, K., Tajima, N., Kadowaki, T., Kashiwagi, A., Araki, E., Ito, C., Inagaki, N., Iwamoto, Y., Kasuga, M., Hanafusa, T., Haneda, M. and Ueki, K. (2010) Report of the Committee on the Classification and Diagnostic Criteria of Diabetes Mellitus. Journal of Diabetes Investigation, 1, 212-228. http://dx.doi.org/10.1111/j.2040-1124.2010.00074.x

[26] Friedewald, W.T., Levy, R.I. and Fredrickson, D.S. (1972) Estimation of the Concentration of Low-Density Lipoprotein Cholesterol in Plasma, without Use of the Preparative Ultracentrifuge. Clinical Chemistry, 18, 499-502.

[27] Expert Panel on Detection (2001) Expert Panel on Detection, Evaluation and Treatment of High Blood Cholesterol in Adults: Executive Summary of the Third Report of the National Cholesterol Education Program Expert Panel on Detection, Evaluation and Treatment of High Blood Cholesterol in Adults (Adult Treatment Panel I II). Journal of the American Medical Association, 285, 2486-2497. http://dx.doi.org/10.1001/jama.285.19.2486

[28] Ye, S., Dhillon, S., Ke, X., Collins, A.R. and Day, I.N. (2001) An Efficient Procedure for Genotyping Single Nucleotide Polymorphisms. Nucleic Acids Research, 29, Article ID: E88. http://dx.doi.org/10.1093/nar/29.17.e88

[29] Zhao, T., Nzekebaloudou, M. and Lv, J. (2010) Ala54Thr Polymorphism of Fatty Acid-Binding Protein 2 Gene and Fasting Blood Lipids: A Meta-Analysis. Atherosclerosis, 210, 461-467. http://dx.doi.org/10.1016/j.atherosclerosis.2009.11.049

[30] Tahvanainen, E., Molin, M., Vainio, S., Tiret, L., Nicaud, V., Farinaro, E., Masana, L. and Ehnholm, C. (2000) Intestinal Fatty Acid Binding Protein Polymorphism at Codon 54 Is Not Associated with Postprandial Responses to Fat and 
Glucose Tolerance Tests in Healthy Young Europeans. Results from EARS II Participants. Atherosclerosis, 152, 317325. http://dx.doi.org/10.1016/S0021-9150(99)00488-8

[31] Gómez, L.C., Real, S.M., Ojeda, M.S., Gimenez, S., Mayorga, L.S. and Roqué, M. (2007) Polymorphism of the FABP2 Gene: A Population Frequency Analysis and an Association Study with Cardiovascular Risk Markers in Argentina. BMC Medical Genetics, 8, 39. http://dx.doi.org/10.1186/1471-2350-8-39

[32] Almeida, J.C., Gross, J.L., Canani, L.H., Zelmanovitz, T., Perassolo, M.S. and Azevedo, M.J. (2010) The Ala54Thr Polymorphism of the FABP2 Gene Influences the Postprandial Fatty Acids in Patients with Type 2 Diabetes. The Journal of Clinical Endocrinology and Metabolism, 95, 3909-3917. http://dx.doi.org/10.1210/jc.2009-2674

[33] Canani, L.H., Capp, C., Ng, D.P., Choo, S.G., Maia, A.L., Nabinger, G.B., Santos, K., Crispim, D., Roisemberg, I., Krolewski, A.S. and Gross, J.L. (2005) The Fatty Acid-Binding Protein-2 A54T Polymorphism Is Associated with Renal Disease in Patients with Type 2 Diabetes. Diabetes, 54, 3326-3330. http://dx.doi.org/10.2337/diabetes.54.11.3326

[34] Albala, C., Santos, J.L., Cifuentes, M., Villarroel, A.C., Lera, L., Libermann, C., Angel, B. and Pérez-Bravo, F. (2004) Intestinal FABP2 A54T Polymorphism: Association with Insulin-Resistance and Obesity in Women. Obesity Research, 12, 340-345. http://dx.doi.org/10.1038/oby.2004.42

[35] Kim, C.H., Yun, S.K., Byun, D.W., Yoo, M.H., Lee, K.U. and Suh, K.I. (2001) Codon 54 Polymorphism of the Fatty Acid Binding Protein 2 Gene Is Associated with Increased Fat Oxidation and Hyperinsulinemia but Not with Intestinal Fatty Acid Absorption in Korean Men. Metabolism, 50, 473-476. http://dx.doi.org/10.1053/meta.2001.21022

[36] Yamada, K., Yuan, X., Ishiyama, S., Koyama, K., Ichikawa, F., Koyanagi, A., Koyama, W. and Nonaka, K. (1997) Association between Ala54Thr Substitution of the Fatty Acid Binding Protein 2 Gene with Insulin Resistance and Intra-Abdominal Fat Thickness in Japanese Men. Diabetologia, 40, 706-710. http://dx.doi.org/10.1007/s001250050737

[37] Boullu-Sanchis, S., Lepretre, F., Hedelin, G., Donnet, J.P., Schaffer, P., Froguel, P. and Pinget, M. (1999) Type 2 Diabetes Mellitus: Association Study of Five Candidate Genes in an Indian Population of Guadeloupe, Genetic Contribution of FABP2 Polymorphism. Diabetes \& Metabolism, 25, 150-156.

[38] Chiu, K.C., Chuang, L.M. and Yoon, C. (2001) The A54T Polymorphism at the Intestinal Fatty Acid Binding Protein 2 Is Associated with Insulin Resistance in Glucose Tolerant Caucasians. BMC Genetics, 2, 7-13. http://dx.doi.org/10.1186/1471-2156-2-7

[39] Duarte, N.L., Colagiuri, S., Palu, T., Wang, X.L. and Wilcken, D.E. (2003) Obesity, Type II Diabetes and the Ala54Thr Polymorphism of Fatty Acid Binding Protein 2 in the Tongan Population. Molecular Genetics and Metabolism, 79, 183-188. http://dx.doi.org/10.1016/S1096-7192(03)00088-X

[40] Hegele, R.A., Harris, S.B., Hanley, A.J., Sadikian, S., Connelly, P.W. and Zinman, B. (1996) Genetic Variation of Intestinal Fatty Acid-Binding Protein Associated with Variation in Body Mass in Aboriginal Canadians. The Journal of Clinical Endocrinology and Metabolism, 81, 4334-4337.

[41] Rissanen, J., Pihlajamäki, J., Heikkinen, S., Kekäläinen, P., Kuusisto, J. and Laakso, M. (1997) The Ala54Thr Polymorphism of the Fatty Acid Binding Protein 2 Gene Does Not Influence Insulin Sensitivity in Finnish Nondiabetic and NIDDM Subjects. Diabetes, 46, 711-712. http://dx.doi.org/10.2337/diab.46.4.711

[42] Ito, K., Nakatani, K., Fujii, M., Katsuki, A., Tsuchihashi, K., Murata, K., Goto, H., Yano, Y., Gabazza, E.C., Sumida, Y. and Adachi, Y. (1999) Codon 54 Polymorphism of the Fatty Acid Binding Protein Gene and Insulin Resistance in the Japanese Population. Diabetic Medicine, 16, 119-124. http://dx.doi.org/10.1046/j.1464-5491.1999.00034.x

[43] Ishii, T., Hirose, H., Kawai, T., Hayashi, K., Maruyama, H., Saito, I. and Saruta, T. (2001) Effects of Intestinal Fatty Acid-Binding Protein Gene Ala54Thr Polymorphism and Beta3-Adrenergic Receptor Gene Trp64Arg Polymorphism on Insulin Resistance and Fasting Plasma Glucose in Young to Older Japanese Men. Metabolism, 50, 1301-1307. http://dx.doi.org/10.1053/meta.2001.27228

[44] Xiang, K., Zheng, T., Jia, W., Sun, D., Ding, W., Lu, J. and Tang, J. (1999) The Impact of Codon 54 Variation in Intestinal Fatty Acid Binding Protein Gene on the Pathogenesis of Diabetes Mellitus in Chinese. Chinese Medical Journal (English Edition), 112, 99-102.

[45] Lei, H.H., Coresh, J., Shuldiner, A.R., Boerwinkle, E. and Brancati, F.L. (1999) Variants of the Insulin Receptor Substrate- 1 and Fatty Acid Binding Protein 2 Genes and the Risk of Type 2 Diabetes, Obesity and Hyperinsulinemia in African-Americans: The Atherosclerosis Risk in Communities Study. Diabetes, 48, 1868-1872. http://dx.doi.org/10.2337/diabetes.48.9.1868

[46] Weiss, E.P., Brown, M.D., Shuldiner, A.R. and Hagberg, J.M. (2002) Fatty Acid Binding Protein-2 Gene Variants and Insulin Resistance: Gene and Gene-Environment Interaction Effects. Physiological Genomics, 10, 145-157.

[47] Zhao, T., Zhao, J., Lv, J. and Nzekebaloudou, M. (2011) Meta-Analysis on the Effect of the Ala54Thr Polymorphism of the Fatty Acid-Binding Protein 2 Gene on Body Mass Index. Nutrition, Metabolism \& Cardiovascular Disease, 21, 823-829. http://dx.doi.org/10.1016/j.numecd.2010.02.020 
[48] de Luis, D.A., Aller, R., Izaola, O., Sagrado, M.G. and Conde, R. (2006) Influence of ALA54THR Polymorphism of Fatty Acid Binding Protein 2 on Lifestyle Modification Response in Obese Subjects. Annals of Nutrition and Metabolism, 50, 354-360.http://dx.doi.org/10.1159/000094299

[49] Huguenin, G.V. and Rosa, G. (2010) The Ala Allele in the PPAR-Gamma 2 Gene Is Associated with Reduced Risk of Type 2 Diabetes Mellitus in Caucasians and Improved Insulin Sensitivity in Overweight Subjects. British Journal of Nutrition, 104, 488-497. http://dx.doi.org/10.1017/S0007114510000851

[50] Stumvoll, M. and Häring, H. (2002) The Peroxisome Proliferator-Activated Receptor-Gamma 2 Pro12Ala Polymorphism. Diabetes, 51, 2341-2347. http://dx.doi.org/10.2337/diabetes.51.8.2341

[51] Lindi, V., Sivenius, K., Niskanen, L., Laakso, M. and Uusitupa, M. (2001) Effect of the Pro12Ala Polymorphism of the PPAR-Gamma 2 Gene on Long-Term Weight Change in Finnish Non-Diabetic Subjects. Diabetologia, 44, 925-926. http://dx.doi.org/10.1007/s001250100558

[52] Ludovico, O., Pellegrini, F., Di Paola, R., Minenna, A., Mastroianno, S., Cardellini, M., Marini, M.A., Andreozzi, F., Vaccaro, O., Sesti, G. and Trischitta, V. (2007) Heterogeneous Effect of Peroxisome Proliferator-Activated Receptor Gamma 2 Ala12 Variant on Type 2 Diabetes Risk. Obesity, 15, 1076-1081. http://dx.doi.org/10.1038/oby.2007.617

[53] Mori, H., Ikegami, H., Kawaguchi, Y., Seino, S., Yokoi, N., Takeda, J., Inoue, I., Seino, Y., Yasuda, K., Hanafusa, T., Yamagata, K., Awata, T., Kadowaki, T., Hara, K., Yamada, N., Gotoda, T., Iwasaki, N., Iwamoto, Y., Sanke, T., Nanjo, K., Oka, Y., Matsutani, A., Maeda, E. and Kasuga, M. (2001) The Pro12Ala Substitution in PPAR-c Is Associated with Resistance to Development of Diabetes in the General Population Possible Involvement in Impairment of Insulin Secretion in Individuals with Type 2 Diabetes. Diabetes, 50, 891-894. http://dx.doi.org/10.2337/diabetes.50.4.891

[54] Mancini, F.P., Vaccaro, O., Sabatino, L., Tufano, A., Rivellese, A.A., Riccardi, G. and Colantuoni, V. (1999) Pro12Ala Substitution in the Peroxisome Proliferator-Activated Receptor-Gamma 2 Is Not Associated with Type 2 Diabetes. Diabetes, 48, 1466-1468. http://dx.doi.org/10.2337/diabetes.48.7.1466

[55] Masugi, J., Tamori, Y., Mori, H., Koike, T. and Kasuga, M. (2000) Inhibitory Effect of a Proline-to-Alanine Substitution at Codon 12 of Peroxisome Proliferator-Activated Receptor-Gamma 2 on Thiazolidinedione-Induced Adipogenesis. Biochemical and Biophysical Research Communications, 268, 178-182. http://dx.doi.org/10.1006/bbrc.2000.2096

[56] Shah, A., Rader, D.J. and Millar, J.S. (2010) The Effect of PPAR-Alpha Agonism on Apolipoprotein Metabolism in Humans. Atherosclerosis, 210, 35-40. http://dx.doi.org/10.1016/j.atherosclerosis.2009.11.010 